\title{
Study on Removal of Heavy Metals from Dumping Leachate by Using Water Hyacinth
}

\author{
Shital G. Rupanawar ${ }^{1}$, Sunil B. Thakare ${ }^{2}$ \\ ${ }^{1}$ Department of Civil-Environmental Engineering, AnantraoPawar College of Engineering and Research, Pune, MS, India \\ ${ }^{2}$ Professor, Department of Civil-Environmental Engineering, AnantraoPawar College of Engineering and Research, Pune, MS, India
}

\begin{abstract}
Due to over human population rate of degradation of environment and pollution increases day by day. As various heavy metals are main pollutant which causes hazardous effects on every living organism. Such a toxic pollutants can be removed from waste water by using physical chemical and biological methods but physical and chemical methods are costly and also causes negative impact on habitats of living organisms. Therefore biological methods such as phytoremediation (water Hyacinth) and eco-friendly method which isNot only eco-friendly but also economically affordable. This research paper proves that study plants can be used to nutralize the hazardous effects of heavy metals.
\end{abstract}

Keywords: Heavy metals, waste water phytoremediation, Ecofriendly, Water Hyacinth (Eichhornia crassipes)

\section{Introduction}

Phytoremediation is an emerging biological method in which various naturally growing aquatic terrestrial plants can be used to remove toxic substances At present the most serious problem of pollution is the direct result of human activity. Some metropolitan cities like Bombay, Calcutta, Bangalore, and Pune are showing typical urban pollution. Among these cities, Pune produces large quantity (1000-2000 mt/day) of Municipal Solid Waste (MSW).The only dumping of all these waste means without any treatment responsible for polluting water resources by leachate is a serious issue occurs in sample collected site.

The leachate consist of various hazardous heavy metals including dissolved organic pollutants Plants are endowed with absorbing pollutants through the roots transport to the leaves and accumulates in their body (goel, 2006).The presence of heavy metals in the leachate of dumping waste material is the main cause of pollution aquatic bodies. Various scientist reported that Eichhornia crassipespossesses potential aquatic to remove heavy metals from aquatic body(Cornell et-al, 1977, Reddy et-al 1990). The recently municipal waste and other industrial waste are treated by using water hyacinth (Kulkarniet-al 2006).The phytoremediation method has been attracting the researchers working in pollution field because of its less financial investment and eco friendliness.

The above information facts prompted us to use water hyacinth in the removal heavy metals from the leachate of dumping waste. Plant based bio-purification technologies have been collectively termed as phytoremediation; This refers to the use of green plants and their associated micro biota for the treatment of contaminated soil, ground and surface water. Large green plants have the capability to move large amounts of solution into the plant body through the roots and evaporate this water out of the leaves as pure water vapour in a process called transpiration.

\section{Materials and Methods}

\section{Collection of experimental plant}

Water hyacinth (Eichhorniacrassipes) obtained from Bhima River in Daund, Maharashtra state, was thoroughly washed with tap water to remove any soil/sediment particles attached to the plant surfaces.

The plants were placed in $1000 \mathrm{ml}$ capacity plastic tub having diameter 5 inch and contaning $250 \mathrm{ml}$ polluted sample in each plastic tube collected from Uruli-Devachi (Hadapsar District Pune) in each plastic tube. To avoid the evaporation plastic tubes were exposed to sun rise $2 \mathrm{hrs}$ per day and kept plastic tubes in the shed.

After 2 Days and 4 Days the plant samples were collected from each sample analysed forIron $(\mathrm{Fe})$, Magnesium $(\mathrm{Mn})$ Zinc (Zn), copper $(\mathrm{Cu})$, Cadmium (Cd), Lead (Pb), Coparameters by using standard methods

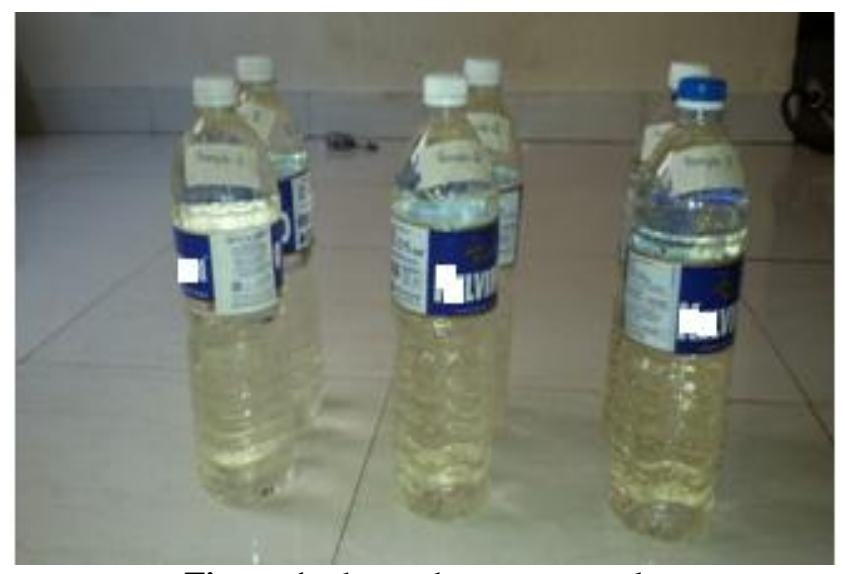

Figure 1: shows the water sample 


\section{International Journal of Science and Research (IJSR) \\ ISSN (Online): 2319-7064}

Index Copernicus Value (2013): 6.14 | Impact Factor (2015): 6.391

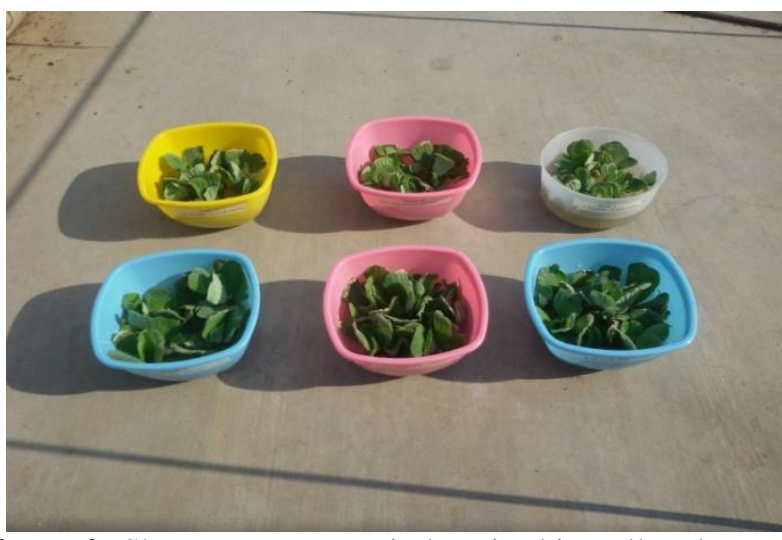

Figure 2: Shows Water Hyacinth Raised in polluted sample

\section{Results and Discussion}

The samples collected from three sites were analysed and then Eichhornia crassipes raised in same samples for 2 and 4 days and again samples were analysed for heavy metals such as heavy metals. The results presented in fig. A, B, C suggested that each toxic element decreased in polluted samples with increase in the days of raising plants. Similar results observed while working on same plant (Padhisushant Kumar et-al).

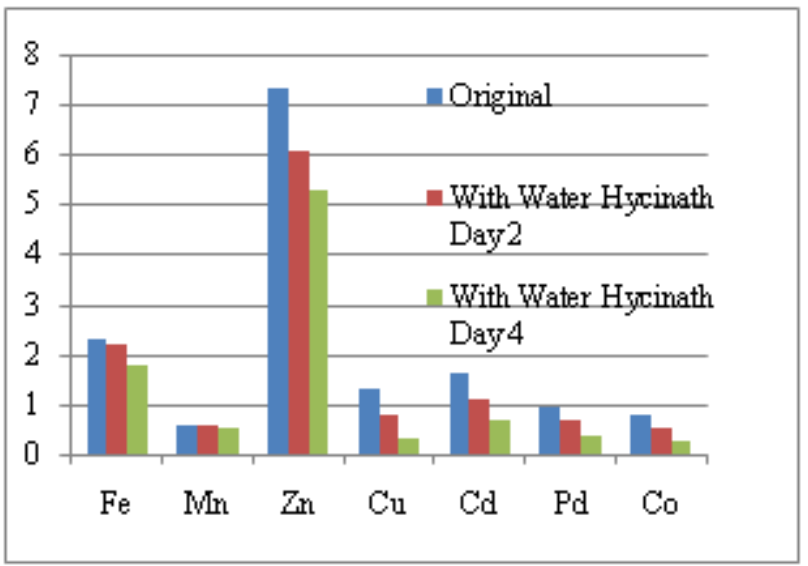

Figure A: Heavy metals in original and two days raised and 4 days raised water hyacinth sample

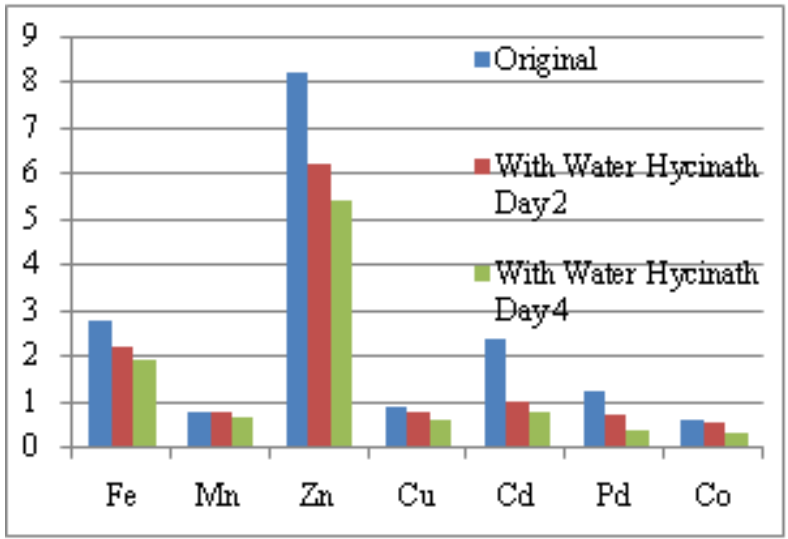

Figure B: Heavy metals in original and two days raised and 4 days raised water hyacinth sample

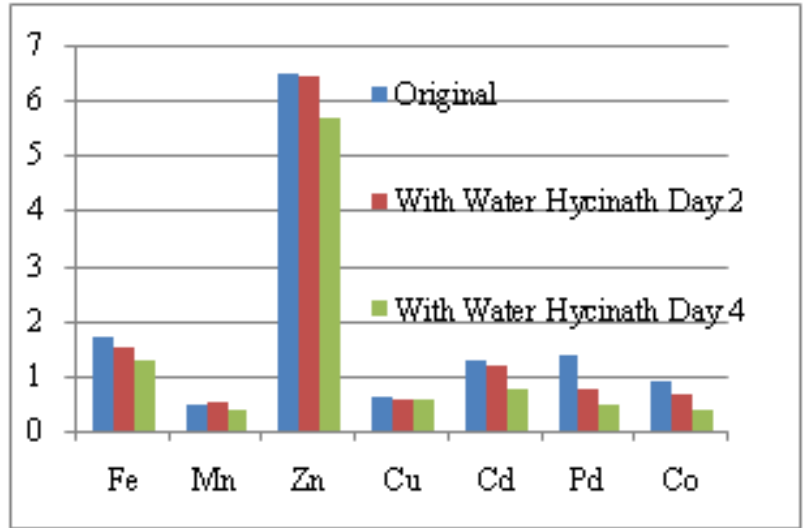

Figure C: Heavy metals in original and two days raised and 4 days raised water hyacinth sample

\section{Conclusion}

The water Hyacinth can be used to remove heavy toxic metals These plants would be best phytoremediation. The plants Eichhornia crassipes Raised in three polluted sample for 4 and 6 days were and then analyses for accumulation of heavy metalsIron $(\mathrm{Fe})$, Magnesium $(\mathrm{Mn})$, Zinc $(\mathrm{Zn})$, copper $(\mathrm{Cu})$, Cadmium $(\mathrm{Cd})$, Lead $(\mathrm{Pb})$, Co.The accumulation of heavy metals in plants.

\section{References}

[1] Central Pollution Control Board, (CPCB, 2000). "Manual OnMunicipal Solid Waste Management", Ministry Of Urban Development, New Delhi, India

[2] Cornell D. A., Zoltek Partinely C. D., Furmen T. and Kim J. I. Nutrient removal by water hyacinth. J. WPCF, 8, 57- 65 (1977)

[3] Reddy K. R., Agami M. and Tuckker J. C., Influence of phosphorous on growth and nutrient storage by water hyacinth (Eichhorniacrassipes). Aquatic botany, 37, 355365 (1990)

[4] Kulkarni B.V., Ranade S. V. and. Wasif A.I., Phytoremediation of textile process effluent by using water hyacinth - A polishing treatment (2006)

[5] Baharudin, B. and Shahrel, Mohd (2008). Lead and cadmium removal in synthetic wastewater using constructed wetland. Faculty of Chemical \& Natural Resources Engineering Universiti, Malaysia Pahang.

[6] P.S.Kumar, S.S.Kumar, Kumari Anuradha, BharatiSudha , Ansari Shahbaj. Phytoremediation as an Alternative for Treatment of Paper Industry Effluents by Using Water Hyacinth (Eichhornia crassipes)-A Polishing Treatment, International Journal of Research in Chemistry and Environment. Vol. 2 Issue 3 July 2012(95-99) ISSN 2248-9649 


\section{International Journal of Science and Research (IJSR) \\ ISSN (Online): 2319-7064}

Index Copernicus Value (2013): 6.14 | Impact Factor (2015): 6.391

HM sample 1

\section{Heavy Metals}

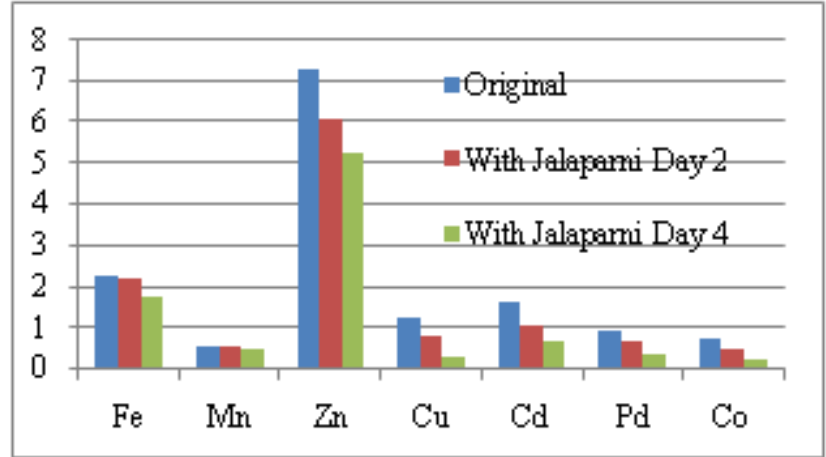

HM Sample 2

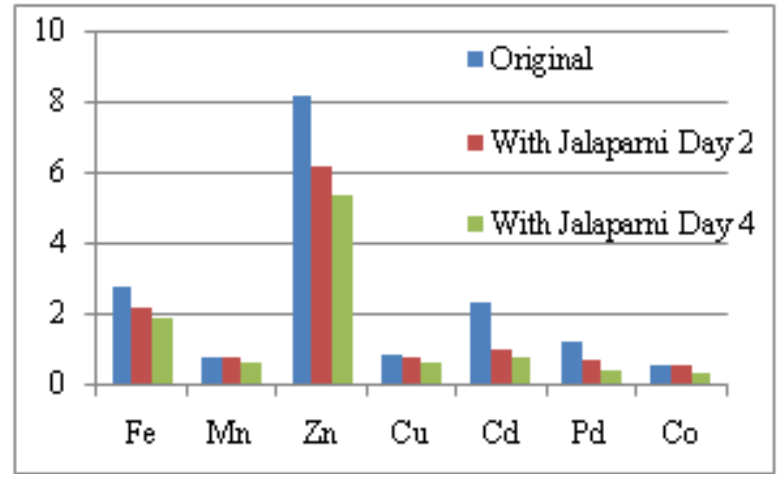

HM sample 3
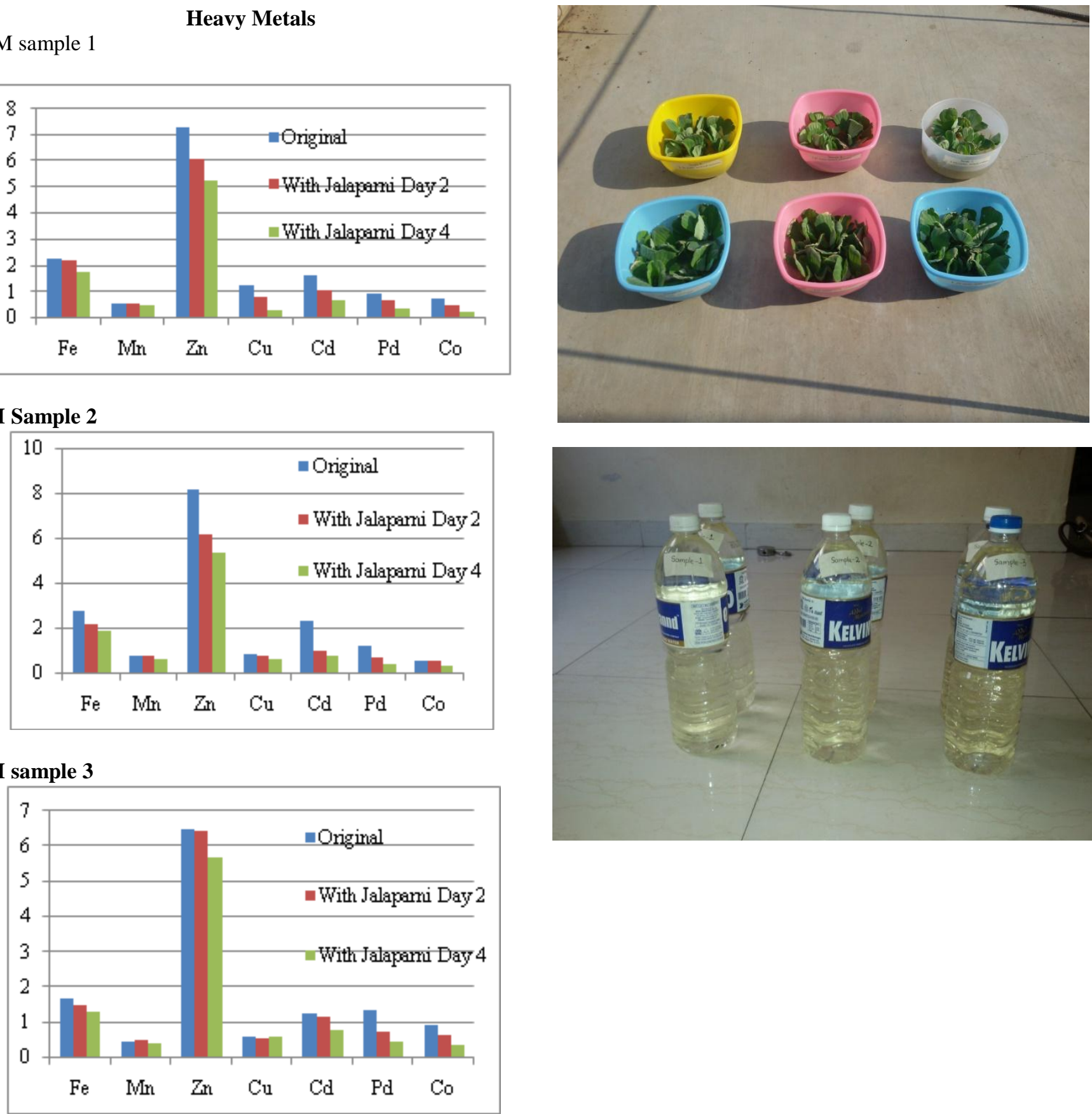

Graph Fig Name - Heavy Metals in Original and two Days Raised and 4 Days Raised Water Hycinth Samples

\begin{tabular}{|c|c|c|c|c|c|c|c|c|}
\hline $\begin{array}{c}\text { Sample } \\
\text { No. }\end{array}$ & $\mathrm{pH}$ & $\mathrm{EC}$ & $\mathrm{Cl}^{-}$ & $\mathrm{HCO}_{3}^{-}$ & $\mathrm{Ca}^{+}$ & $\mathrm{Mg}^{+}$ & $\mathrm{Na}^{+}$ & $\mathrm{No}_{3}{ }^{-} \mathrm{N}$ \\
\hline \multicolumn{8}{|c|}{ Original Sample } \\
\hline 1 & 7.32 & 3.18 & 20.2 & 8.8 & 15.57 & 7.27 & 6.09 & 9.59 \\
\hline 2 & 7.41 & 3.34 & 23.4 & 8.4 & 14.35 & 6.26 & 8.70 & 6.75 \\
\hline 3 & 7.57 & 2.45 & 18.8 & 5.2 & 10.45 & 7.05 & 7.09 & 6.66 \\
\hline \multicolumn{8}{|c|}{ Adding water Hyacinth-Day 2 } \\
\hline 1 & 7.62 & 2.45 & 17.6 & 6.2 & 9.86 & 4.48 & 4.89 & 5.85 \\
\hline 2 & 7.59 & 2.35 & 18.4 & 5.9 & 10.29 & 4.81 & 6.07 & 5.68 \\
\hline 3 & 7.63 & 2.27 & 16.9 & 6.6 & 10.07 & 4.9 & 6.29 & 4.94 \\
\hline \multicolumn{8}{|c|}{ Adding water Hyacinth-Day 4 } \\
\hline 1 & 7.65 & 1.75 & 15.5 & 3.8 & 7.05 & 2.25 & 3.19 & 5.20 \\
\hline 2 & 7.64 & 1.75 & 16.4 & 3.4 & 7.46 & 2.60 & 4.45 & 4.99 \\
\hline 3 & 7.66 & 1.97 & 16.0 & 3.2 & 7.57 & 2.65 & 5.97 & 4.25 \\
\hline
\end{tabular}

\section{Volume 5 Issue 6, June 2016} www.ijsr.net

Licensed Under Creative Commons Attribution CC BY 